\title{
Electrocardiographic parameters in captive, clinically healthy, Amazona ochrocephala
}

\section{Parámetros electrocardiográficos en Amazona ochrocephala clínicamente sanas en cautiverio}

\author{
Claudia Guerrero S, ${ }^{1} \mathrm{MV}$, Janeth Bolivar $\mathrm{B},{ }^{1} \mathrm{MV}$, Piero Vargas-Pinto,${ }^{1 *} \mathrm{MV}$, \\ Pedro Vargas-Pinto, ${ }^{2}$ Ph. D, Claudia Brieva-Rico, ${ }^{1}$ M.Sc.
}

${ }^{1}$ Universidad Nacional de Colombia, Facultad de Medicina Veterinaria y Zootecnia, Departamento de Salud Animal, Carrera 30\#45. Bogotá, Colombia. ${ }^{2}$ Universidad de la Salle. Facultad de Ciencias Agropecuarias, Carrera 70 \# 172-85. Bogotá, Colombia. ${ }^{*}$ Correspondencia: piavargaspi@unal.edu.co.

Received: September 2014; Acepted: February 2015.

\begin{abstract}
Objective. To stablish the electrocardiographic parameters of individuals of the species Amazona ochrocephala, from the Unidad de Rescate y Rehabilitacion de Animales Silvestres at the Universidad Nacional de Colombia. Materials and methods. The electrocardiographic examination was performed under inhaled anesthesia with isoflurane. Leads I, II, III, aVL, aVR and aVF were measured. Results. Electrocardiographic parameters obtained in Lead II. P wave Duration: 0.015-0.044 S, P wave amplitude: 0.031 to $0.6 \mathrm{mv}$, R wave duration: $0.015-0.022 \mathrm{~s}$, amplitude R: $0.034-0.038 \mathrm{mv}$, S wave Duration: 0.019- $0.042 \mathrm{~s}$, amplitude S: 0.194-0.815 mv, T wave Duration: 0.025-0.064 s, T-wave amplitude: 0.010 to $0.5 \mathrm{mv}$, PQ Duration: $0.021-0.076 \mathrm{~s}$, QRS Duration: $0.036-0.068 \mathrm{~s}$, QT Duration: 0.070-0.015 s, RR Duration: $0.104-0.324$ s, EEM: $-111^{\circ}$ to $-80^{\circ}$, FC: $240-600 \mathrm{ppm}$. Conclusions. The results showed different values for amplitude and duration of the $\mathrm{P}, \mathrm{R}$ and $\mathrm{T}$ waves in comparison to those obtained in other studies. However, they were similar for heart rate, MEA and duration of the $\mathrm{PQ} / \mathrm{R}, \mathrm{QT}$ and $\mathrm{QRS}$ segments.
\end{abstract}

Key words: Amazona ochrocephala, diagnosis, electrocardiography. (Sources: MeSH).

\section{RESUMEN}

Objetivo. Establecer los parámetros electrocardiográficos en individuos de la especie Amazona ochrocephala, de la Unidad de Rescate y Rehabilitación de Animales Silvestres de la Universidad Nacional de Colombia sede Bogotá. Materiales y Métodos. El examen electrocardiográfico se realizó bajo anestesia inhalada con Isoflurano. Se tomaron derivadas I, II, III, aVL, aVR y aVF y posterior medición de ondas e intervalos usando magnificación con lupa. Resultados. Parámetros electrocardiográficos de la segunda derivada. Duración onda P: 0.015-0.044 s, amplitud onda P: 0.031-0.6 mv, duración onda R: 0.015-0.022 s, amplitud R: 0.034-0.038 mv, Duración onda S: 0.019- 0.042 s, Amplitud S: 0.194-0.815 mv, Duración onda T: 0.025-0.064 s, Amplitud onda T: 0.010-0.5 mv, Duración PQ: 0.021-0.076 s, Duración QRS: 0.036-0.068 s, Duración QT: 0.070-0.015 s, Duración R-R: 0.104-0.324 S, EEM: $-111^{\circ} \mathrm{a}-80^{\circ}$, FC: $240-600 \mathrm{ppm}$. Conclusiones. Los resultados mostraron valores diferentes para los rangos de amplitud y duración de las deflexiones $\mathrm{P}$, R y T en comparación a los obtenidos en otros estudios pero similares en cuanto al rango de frecuencia cardiaca, EEM y a la duración de los segmentos PQ/R, QT y QRS.

Palabras clave: Amazona ochrocephala, diagnóstico, electrocardiografía. (Fuentes: MeSH). 


\section{INTRODUCTION}

The yellow-crowned parrot (Amazona ochrocephala) belongs to the psittacidae family that inhabits forests, mangroves, and tropical forests on the American continent. Although in Colombia this species is in a "least concerned" conservation state, in the country it is one of the wild birds that is most sold due to its demand as a pet, which is an illegal practice $(1,2)$ and they are often caught by the environmental authorities and turned over fauna centers such as the Unidad de Rescate y Rehabilitación de Animales Silvestres (URRAS) of the National University of Colombia.

These birds differ significantly from mammals in their cardiovascular functions (3) and greater research is needed to understand the physiology, pathology and diagnostic methods. Additionally, environmental and nutritional changes of those that are taken to different habitats can alter their normal cardiovascular functioning. One of the most frequently used diagnostic tests in cardiology is electrocardiography (2), and reference values for chickens, turkey, doves and Amazona parrots are available. There is also information (mostly taken from domestic species) on the physiologic and anatomic traits of the cardiovascular system of these birds (3), as well as certain diagnostic procedures on diseases and their treatments. However, there is little information on electrocardiography on Amazona parrots and the authors have not come across studies that report the normal values for electrocardiography parameters for a determined parrot species; a similar study conducted in 1992 took individuals from the Amazona ochrocephala, A. festiva and $A$. amazonica species to obtain references for ECG parameters (4).

Due to this tendency and the lack of information available concerning normal values for electrocardiographic parameters in this species, the objective of this study was to determine the ECG parameters in Amazona ochrocephala from the Unidad de Rescate y Rehabilitación de Animales Silvestres (URRAS) of the Universidad Nacional de Colombia, Bogotá headquarters.

\section{MATERIALS AND METHODS}

Type of study. A non-experimental, transversal type descriptive study was conducted in the period between August and October 2013.

Study site and geoclimate. Unidad de rehabilitación de Animales Silvestres (URRAS), Clínica para Pequeños Animales (CPA) of the Faculty of Veterinary Medicine and Zootechnics, National University of Colombia. Latitude: $4^{\circ} 35^{\prime} 46.3215^{\prime \prime} \mathrm{N}$

\section{INTRODUCCIÓN}

El loro real (Amazona ochrocephala) es un ave perteneciente a la familia psittacidae que habita bosques, manglares y zonas selváticas tropicales del continente americano. Aunque en Colombia esta especie se encuentra en estado de conservación "preocupación menor" es una de las aves silvestres que más se trafican en el país debido a su demanda como mascota, lo que representa una práctica ilegal $(1,2)$ por lo cual corresponden a una gran parte de los animales incautados por las autoridades ambientales y que ingresan a centros de fauna como la Unidad de Rescate y Rehabilitación de Animales Silvestres (URRAS) de la Universidad Nacional de Colombia.

Las aves poseen diferencias bastante significativas con los mamíferos en su funcionamiento cardiovascular (3) por lo cual requieren mayor investigación en cuanto a la fisiología, patología y métodos diagnósticos. Adicionalmente los cambios medioambientales y nutricionales a los que son sometidas al ser llevadas a hábitats diferentes a los de su medio pueden alterar el funcionamiento cardiovascular normal. Una de las técnicas diagnósticas más utilizadas en el campo de la cardiología es la electrocardiografía (2), teniendo actualmente valores de referencia en especies de pollos, pavos, palomas y loras del género Amazona. También existe información (que en su mayoría se extrapola de otras especies domesticas) sobre las características fisiológicas y anatómicas del sistema cardiovascular de las aves (3), además de ciertos procedimientos diagnósticos, enfermedades y tratamientos. Sin embargo es poca la información que se encuentra sobre electrocardiografía en loras del género Amazona y los autores no conocen la existencia de estudios que reporten los valores normales de parámetros electrocardiográficos para una especie determinada de lora; en un estudio similar realizado en el año 1992 se tomaron individuos de las especies Amazona ochrocephala, A. festiva y A. amazónica para obtener parámetros electrocardiográficos de referencia (4).

Debido a esta tendencia y a la poca información disponible sobre los valores normales de parámetros electrocardiográficos para ésta especie, el objetivo de este estudio fue determinar los parámetros electrocardiográficos en individuos de la especie Amazona ochrocephala de la Unidad de Rescate y Rehabilitación de Animales Silvestres (URRAS) de la Universidad Nacional de Colombia, sede Bogotá.

\section{MATERIALES Y MÉTODOS}

Tipo de estudio. Se realizó un estudio no experimental, descriptivo de tipo transversal en el periodo comprendido entre Agosto y Octubre de 2013. 
Longitude: $74^{\circ} 4^{\prime} 39.0285^{\prime \prime} \mathrm{W}$ (5) Altitude: 2560 msnm, average $\mathrm{T}^{\circ}: 13.8^{\circ} \mathrm{C}$, relative humidity: 73$80 \%$ (6); atmospheric pressure $560 \mathrm{mmHg}$ (7).

Study population. Birds from the Amazona ochrocephala species $(n=17)$ kept in individual cages and group enclosures with perches, thermic support and elements to enrich the environment. Fed with a special diet for this species which is composed of fruit, vegetables, seeds, and vitamin and mineral supplements.

Ethic aspects. The study was conducted with the approval of the Bioethics Committee of the Faculty of Veterinary Medicine and Zootechnics, National University of Colombia, in session from August 14, 2013 (Act 06).

Electrocardiographic record. Before the ECG exam, a basic clinical exam was performed, evaluating the state of hydration, cardiovascular and lung functionality, temperature and weight. For the ECG exam, the animals were put under anesthesia, inhaled with isoflurane between 3-4\% for induction (with mask) and 1.5 - 2\% for maintenance; tubing was done with endotracheal tube No. 2 or 3 without balloon. With animals in supine position, alligator clips were used for the electrocardiographic procedure, connecting them to the fold of the wings and the thighs (Figure 1). Gel and diluted alcohol was used to improve electric conduction. The ECG record was taken both in bipolar as well as increased unipolar derivatives (ECG Biocare 101G, China) (Figure 2 and 3) with a paper speed of $50 \mathrm{~mm} / \mathrm{s}$ and an amplitude of $20 \mathrm{~mm} / \mathrm{mv}$ (8). Anesthesia monitoring was performed by taking heart rate, respiration and temperature. Thermal support was provided during and after the procedure.

Obtaining electrocardiographic parameters. The ECG analysis was performed using five continuous qRs complexes with adequate morphology, measuring each one of the waves and intervals for duration and amplitude in every derivative taken, with the aid of magnifying glass in cases where the deflections were very small (Figure 4). To calculate the mean electric axis, Bailey Axis system was used, taking the sum of the positive and negative deflections ( $R$ and $S$ ) that represent ventricular depolarization of leads I and III and taking the point where these measurements transpose (9).

Statistical analysis. Data obtained by manual measurements was entered onto a form in Microsoft Excel ${ }^{\circledR}$ version 2010 (Microsoft Corporation ${ }^{\circledR}$ ), and a descriptive statistical analysis was compiled. The final results were obtained through averages, standard deviation, minimum and maximum values, which were presented in tables and charts.
Sitio de estudio y geoclima. Unidad de rehabilitación de Animales Silvestres (URRAS), Clínica para Pequeños Animales (CPA) de la Facultad de Medicina Veterinaria y Zootecnia, Universidad Nacional de Colombia, Bogotá. Latitud: 4³5'46.3215"N Longitud: 744'39.0285"W (5) Altitud: $2560 \mathrm{msnm}$, $\mathrm{T}^{\circ}$ media: $13.8^{\circ} \mathrm{C}$, Humedad relativa: $73-80 \%$ (6); presión atmosférica 560 $\mathrm{mmHg}(7)$.

Población de estudio. Aves de la especie Amazona ochrocephala $(n=17)$, alojadas en jaulas individuales y encierros grupales con perchas, soporte térmico y elementos de enriquecimiento ambiental. Alimentadas con una dieta especial para ésta especie, la cual se componía de frutas, verduras, semillas, suplementos vitamínicos y minerales.

Aspectos éticos. El estudio se realizó bajo la aprobación del Comité de Bioética de la Facultad de Medicina Veterinaria y Zootecnia de la Universidad Nacional de Colombia, en sesión del 14 de agosto de 2013 (acta 06).

Registro electrocardiográfico. Previo al examen electrocardiográfico se practicó un examen clínico básico, evaluando el estado de hidratación, funcionalidad cardiovascular, pulmonar, temperatura y pesaje. Para el examen

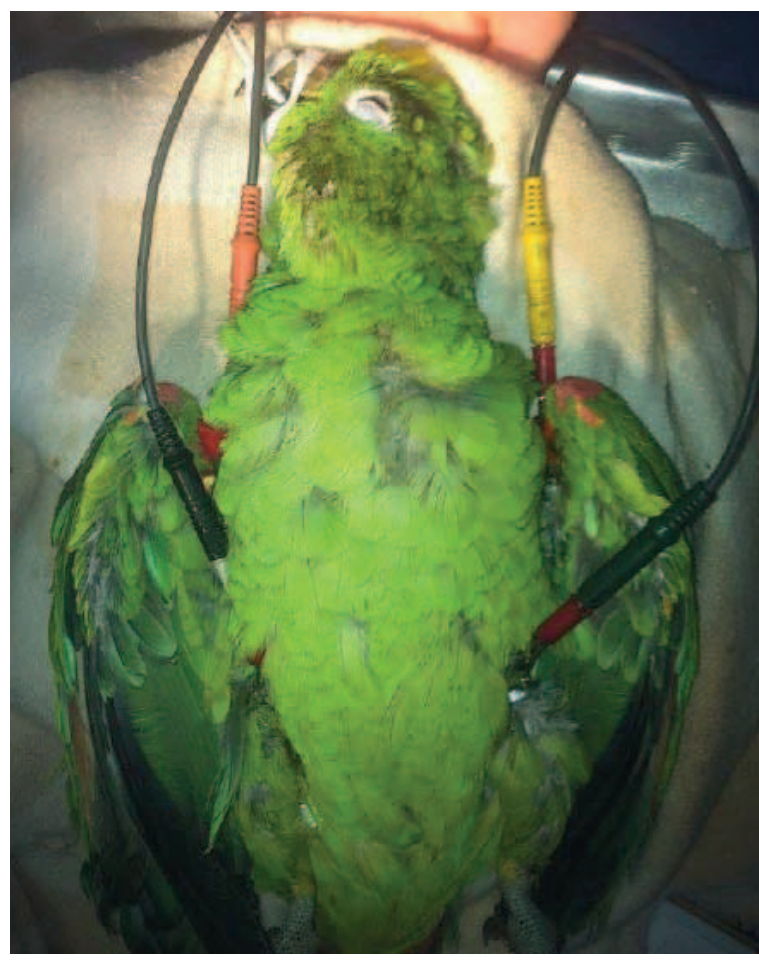

Figure 1. Electrode position for Amazona ochrocephala parrot. Red and yellow cables in superior members in the dorsal fold of the wing, black and green cable on inferior members on the knee joint. 


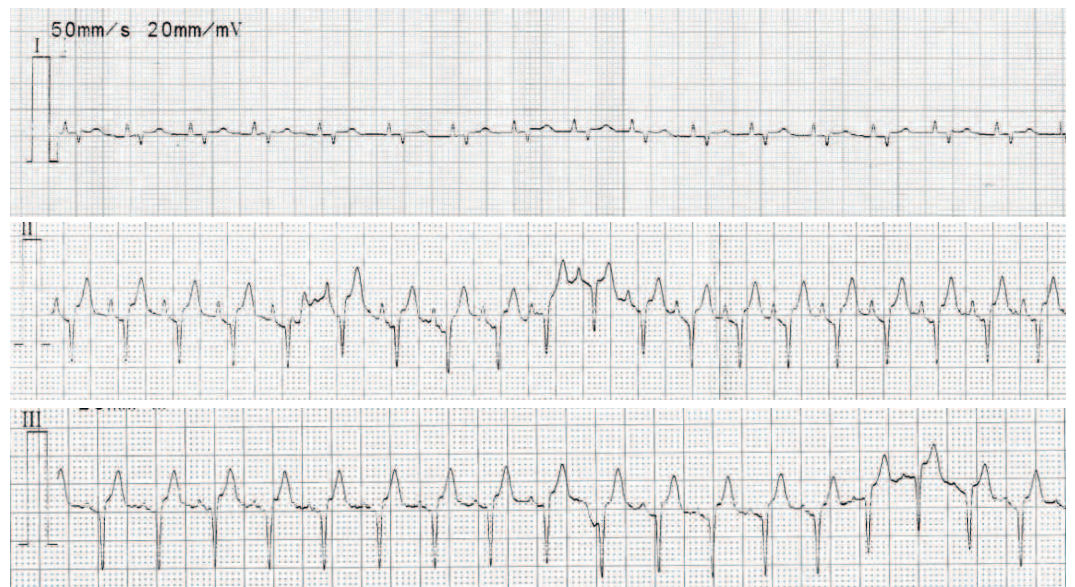

Figure 2. Normal ECG tracing in Amazona ochrocephala parrots. Bipolar leads: a) I, b) II, c) III. At a speed of $50 \mathrm{~mm} / \mathrm{s}$ and $20 \mathrm{~mm} / \mathrm{mv}$.
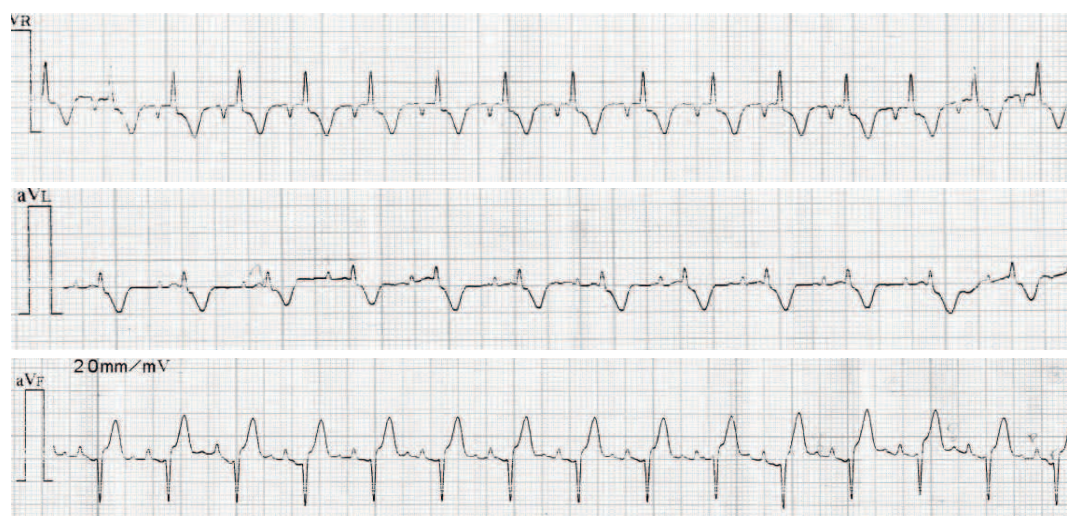

Figure 3. Normal ECG tracing in Amazona ochrocephala parrots. Augmented monopolar leads: a) aVR, b) aVL, c) aVF. At a speed of $50 \mathrm{~mm} / \mathrm{s}$ and $20 \mathrm{~mm} / \mathrm{mv}$.

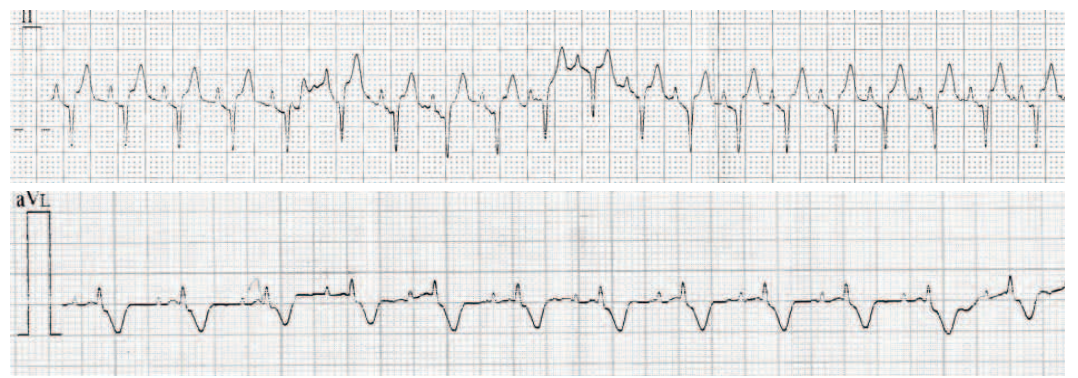

Figure 4. Normal ECG tracing in Amazona ochrocephala parrots for lead II. a) Waves $\mathrm{P}, \mathrm{r}, \mathrm{S}, \mathrm{T}$; b) Segments Pq, qrS, qT. At a speed of $50 \mathrm{~mm} / \mathrm{s}$ and $20 \mathrm{~mm} / \mathrm{mv}$.

\section{RESULTS}

The electrocardiograph technique used in this study made it possible to measure the heart rate in all the cases $(n=17)$, and deflections and intervals in the majority of the parrots. The ECG parameters for lead II are illustrated in tables 1 and 2.

The heart rate was found between 240 y 600 electrocardiográfico los animales fueron puestos bajo anestesia inhalada con isoflurano entre el $3-4 \%$ para la inducción (con mascarilla) y el 1.5 - 2\% para el mantenimiento; la intubación se realizó con sonda endotraqueal No. 203 sin balón. Con los animales en decúbito dorsal, se utilizaron clips de caimán para el procedimiento electrocardiográfico, ubicándolos en el pliegue de las alas y de los muslos (Figura 1); se utilizó gel y alcohol diluido para mejorar la conducción eléctrica. 
Table 1. Reference values for electrocardiographs in healthy $A$. ochrocephala in Lead II.

\begin{tabular}{ccccc}
\hline Parameter & Average & $\begin{array}{c}\text { Standard } \\
\text { deviation }\end{array}$ & $\begin{array}{c}\text { Minimum } \\
\text { value }\end{array}$ & $\begin{array}{c}\text { Maximum } \\
\text { value }\end{array}$ \\
\hline Amplitude P (mV) & 0.178 & 0.156 & 0.031 & 0.6 \\
Duration P (ms) & 25.108 & 9.222 & 15.2 & 44 \\
Amplitude R (mV) & 0.035 & 0.002 & 0.034 & 0.038 \\
Duration R (ms) & 19.733 & 3.925 & 15.2 & 22 \\
Amplitude S (mV) & 0.566 & 0.187 & 0.194 & 0.815 \\
Duration S (ms) & 23.976 & 5.996 & 19.2 & 42 \\
Amplitude T (mV) & 0.284 & 0.163 & 0.011 & 0.585 \\
Duration T (ms) & 48.04 & 11.019 & 26 & 64 \\
\hline
\end{tabular}

Table 2. Reference values for electrocardiographs in healthy $A$. ochrocephala in Lead II.

\begin{tabular}{ccccc}
\hline Parameter & Average & $\begin{array}{c}\text { Standard } \\
\text { deviation }\end{array}$ & $\begin{array}{c}\text { Minimum } \\
\text { value }\end{array}$ & $\begin{array}{c}\text { Maximum } \\
\text { value }\end{array}$ \\
\hline Duration PQ (ms) & 47.169 & 14.652 & 21.6 & 76 \\
QT Corrected (ms) & 16.365 & 9.893 & 0 & 27.63 \\
Duration QT (ms) & 119.338 & 22.022 & 70 & 154 \\
Duration QRS (ms) & 48.461 & 8.532 & 36 & 68 \\
Duration R-R (ms) & 168.894 & 56.654 & 104 & 324 \\
\hline
\end{tabular}

beats/minute with an average of 426 beats/ minute (SD 115 beats/minute). (Table 3).

P wave. This wave could only be measured in $76.47 \%$

Table 3. Reference values for electrocardiographs in healthy A. ochrocephala in Lead II.

\begin{tabular}{ccccc}
\hline Parameter & Average & $\begin{array}{c}\text { Standard } \\
\text { deviation }\end{array}$ & $\begin{array}{c}\text { Minimum } \\
\text { value }\end{array}$ & $\begin{array}{c}\text { Maximum } \\
\text { value }\end{array}$ \\
\hline $\begin{array}{c}\text { Heart rate } \\
(\mathrm{ppm})\end{array}$ & 426.470 & 115.377 & 240 & 600 \\
EEM $\left(^{\circ}\right)$ & -94.769 & -34.721 & -111 & -80 \\
\hline
\end{tabular}

of the parrots $(n=13)$ for lead II, which was the most frequent one. In the majority of cases it was presented as a positive wave, with the exception of the aVL lead in which $33.33 \%$ ( 4 of 12 waves) of the waves were negative.

$\mathbf{R}$ wave. This wave was difficult to observe in the ECG tracing, since in the majority of cases it was absent or reading was impossible due to its size. Lead II could only be measured in $17.64 \%$ of the cases $(n=3$ parrots). In aVR and aVL leads it was more difficult to find this wave, in 82.35 and $76.47 \%$ of the cases respectively.

S wave. A difficult wave to observe in augmented unipolar leads, in lead II a reliable measurement was taken in $76.47 \%$ of the cases ( $n=13$ parrots). There was a negative deflection in all the parrots in all leads.

T wave. For lead II this wave could be measured in
El registro electrocardiográfico se tomó tanto en derivadas bipolares como unipolares aumentadas (ECG Biocare 101G, China) (Figura 2 y 3) a una velocidad de papel de $50 \mathrm{~mm} / \mathrm{s}$ y a una amplitud de $20 \mathrm{~mm} / \mathrm{mv}$ (8). Se realizó monitoreo anestésico tomando la frecuencia cardiaca, respiratoria y temperatura. Se dio soporte térmico durante y después del procedimiento.

O b te nción de parámetros electrocardiográficos. El análisis electrocardiográfico se realizó utilizando cinco complejos qRs continuos con una adecuada morfología, midiendo cada una de las ondas e intervalos en duración y amplitud, en todas las derivadas tomadas con ayuda de magnificación con lupa en los casos en que las deflexiones eran muy pequeñas (Figura 4). Para calcular el eje eléctrico medio se utilizó el sistema hexaxial de Baileys tomando la suma de las deflexiones positivas y negativas ( $R$ y $S$ ) que representan la despolarización ventricular de las derivadas I y III y tomando el punto en el cual estas medidas se transponen (9).

Análisis estadístico. Los datos obtenidos en la medición manual fueron ingresados a una planilla de Microsoft Excel ${ }^{\circledR}$ versión 2010 (Microsoft Corporation ${ }^{\circledR}$ ) y se realizó un análisis estadístico de tipo descriptivo. Los resultados finales se obtuvieron a través de promedios, desviación estándar, valores mínimos y máximos, los cuales fueron representados mediante tablas y cuadros.

\section{RESULTADOS}

La técnica electrocardiográfica empleada en este estudio permitió la medición de la frecuencia cardiaca en la totalidad de los casos $(n=17)$, y de las deflexiones e intervalos en la gran mayoría de las loras. Los parámetros electrocardiográficos para la derivada II, se ilustran en las tablas 1 y 2 .

La frecuencia cardiaca se encontró entre 240 y 600 latidos/minuto, con un promedio de 426 latidos / minuto (SD 115 latidos/minuto). (Tabla 3).

Onda P. Esta onda solo pudo ser medida en el $76.47 \%$ de las loras $(n=13)$ para la derivada II, siendo ésta derivada en la que se presentó con mayor frecuencia. En la gran mayoría de los casos estuvo representada como una onda positiva, a excepción de la derivada aVL en la cual el $33.33 \%$ (4 de 12 ondas) de las ondas fueron negativas.

Onda R. Esta onda fue de difícil observación en el trazado electrocardiográfico ya que en la mayoría de los casos se encontraba ausente o su lectura era imposible debido a su tamaño. En la derivada II solo se pudo medir en el $17.64 \%$ de los casos 
$94.11 \%$ of the cases $(n=16)$, in the majority as a positive deflection of $93.75 \%$ and a negative one of $6.25 \%$ in just one parrot. In leads III and aVF, the deflections were completely positive, just the opposite of leads aVR and aVL. For lead I the deflection was mostly positive at $81.25 \%$.

PQ, QT, QRS intervals. These intervals could be measures in $76.47 \%$ of the cases $(n=13)$, for lead II. (Table 2). To discover the QT interval independent of the heart rate, this value was calculated using the Friederichia $Q t c=\frac{Q T}{\sqrt[2]{R R}}$ value of the corrected QT in Lead II, with an average of $16.365 \mathrm{~ms}$ and a standard deviation of $9.893 \mathrm{~ms}$.

R-R intervals. For lead II this interval had an average duration of $168.894 \mathrm{~ms}$ with a standard deviation of $56.654 \mathrm{~ms}$, this interval produced similar values in all the leads.

\section{DISCUSSION}

Due to being exposed to environmental factors that are different from their habitat, as well as handling in captivity, wild birds are prone to develop cardiovascular abnormalities that can harm their well-being and life $(10,11)$. Changes in temperature, humidity, altitude and pressure, as well as a lack of exercise and inadequate diets, can result in cardiovascular diseases such as arteriosclerosis, pulmonary hypertension and congestive heart failure, among others. Reported heart abnormalities range from 9.7 to $36 \%$ (12).

Although ECGs in birds is similar to those used in mammals, there are some differences and chemical restriction or general anesthesia is often required during the procedure, as well as the use of subcutaneous electrodes. The ECG exam under general anesthesia with isoflurane (between 1 and $4 \%$ ) was safe and a good quality tracing was obtained for the majority of the ECGs recorded, with little interference caused by movements of the animals or electrodes. Also, during the study there were no complications due to anesthesia and postsurgical effects were minimal (emesis and hypothermia).

Regarding the ECG record, the most significant differences have to do with phenomenon such as superimposing $T$ and $P$ waves, the presence of $T_{a}$ waves, the absence of $Q$ and $R$ waves on some occasions, QRS complexes and short or absent ST segments. Both in presentation such as size and quality in the deflections recorded in the ECG vary in each lead and with each animal. In lead I, the majority of animals presented an isoelectric tracing with
( $n=3$ loras). En las derivadas aVR y aVL fue más fácil encontrar ésta onda, en el 82.35 y $76.47 \%$ de los casos respectivamente.

Onda S. Onda de difícil observación en las derivadas monopolares aumentadas, en la derivada II se realizó una medición confiable en el $76.47 \%$ de los casos ( $n=13$ loras). Encontrándose en todas las loras como una deflexión negativa, para todas las derivadas.

Onda T. Para la derivada II esta onda fue posible medirla en el $94.11 \%$ de los casos $(n=16)$, mostrando en su mayoría una deflexión positiva $93.75 \%$ y negativa en un $6.25 \%$ presentándose en un solo loro. En las derivadas III y aVF, las deflexiones fueron en su totalidad positivas, al contrario de lo sucedió con las derivadas aVR y aVL. Para la derivada I la deflexión fue en su mayoría positiva $81.25 \%$.

Intervalo PQ, QT, QRS. Estos intervalos pudieron ser medidos en el $76.47 \%$ de los casos $(n=13)$, para la derivada II. (Tabla 2). Para conocer el valor del intervalo QT, independiente de la frecuencia cardiaca, se calculó este valor utilizando la fórmula de Friederichia $Q t_{c}=\frac{Q T}{\sqrt[3]{R R}}$ el valor del QT corregido en Derivada II tuvo un promedio de $16.365 \mathrm{~ms}$ y una desviación estándar de 9.893 ms.

Intervalo R-R. Para la derivada II este intervalo tuvo una duración promedio de 168.894 ms con una desviación estándar de 56.654 ms, este intervalo mostró valores similares en todas las derivadas.

\section{DISCUSIóN}

Debido a la exposición a factores medioambientales diferentes a los de su medio y al manejo en cautividad, las aves silvestres son propensas a desarrollar anormalidades del sistema cardiovascular que pueden comprometer su vida y su bienestar $(10,11)$. El cambio de temperatura, la humedad, altitud y presión, al igual que la falta de ejercicio y dietas inadecuadas, pueden favorecer la presentación de enfermedades cardiovasculares como arterioesclerosis, hipertensión pulmonar y falla cardiaca congestiva, entre otras. La presentación de anormalidades cardiacas reportadas va desde el 9.7 hasta el $36 \%$ (12).

Aunque la técnica electrocardiográfica en aves es similar a la utilizada en mamíferos, existen algunas diferencias y pueden requerir restricción química o anestesia general durante el procedimiento, así como el uso de electrodos subcutáneos. El examen electrocardiográfico bajo anestesia general con isoflurano (entre el 1 y $4 \%$ ) fue seguro y permitió obtener un trazado de muy buena calidad para la mayoría de los ECGs registrados, con poco ruido 
very small deflections and complex QRS that were difficult to define.

The aVL lead was more homogenous among all the animals, with regular tracing, good quality and the majority of the deflections were present and easy to measure. As far as the deflections, the $\mathrm{P}$ wave in all the leads was too small, making it difficult to get a reliable reading, while the $R$ wave was difficult to obtain in the majority of the bipolar leads, though not so in the augmented unipolar leads where it was frequently recorded. The $S$ wave was absent or difficult to distinguish in the aVR and aVL leads, while in the other leads it was easily identified. Only two birds (lead I and aVL) did not show any deflection that represented ventricular depolarization ( $R$ or $S$ wave). On the other hand, the $T$ wave was present in all the leads in almost all the animals examined.

As in other species, infectious and noninfectious diseases have been reported to alter the ECG parameters, causing phenomena such as lengthening waves $(P, R, S, T)$, intervals (PR, TP and QRS), tachycardia and ventricular arrhythmia, premature ventricular contractions, bradycardia and high $\mathrm{T}$ waves (13-16). Although the birds used in this study were apparently healthy, it cannot be ruled out that some type of pathology could have affected the ECG results.

In a study done on birds of prey, a wide variability in the morphology of the $\mathrm{P}$ wave in lead III was found [positive in $72.5 \%$, negative in $15.7 \%$ and biphasic in $11.8 \%$ of the animals] (8). In this study, the $P$ wave was always positive in leads I, II, III and aVF, negative in aVR, an positive in $60 \%$ of the animals and negative in $40 \%$ in aVL. It was also observed that $\mathrm{T}$ and $\mathrm{P}$ waves were fused or superimposed in $17.6 \%$ of the animals ( 3 of 17 animals) in leads II, III and aVF, and in the majority of recorded ECGs the $\mathrm{Q}$ and $\mathrm{R}$ waves were absent or too small to be measured.

Finally, it is possible to conclude that a very good quality ECG tracing was obtained when doing the procedure under general anesthesia with Isoflurane (Table 4). Additionally, the results were similar to those reported in the study done by Nap et al (4) with reference to the duration of $\mathrm{P}, \mathrm{QRS}$ and $\mathrm{T}$ waves, heart rate and electric axis, while the amplitude of $P, Q R S$ and T waves was lower in our study. However, these differences can be due to the conditions of each study; in the Nap et al (4) study, Amazona ochrocephala, A. amazónica and $A$. festiva parrots were used, while in this causado por movimientos del animal o de los electrodos. Además durante todo el estudio no se presentó ninguna complicación durante la anestesia y los efectos postquirúrgicos fueron mínimos (emesis e hipotermia).

En cuanto al registro electrocardiográfico, las diferencias más significativas comprenden fenómenos como la superposición de las ondas $T$ y $P$, la presencia de la onda $T_{a}$, la ausencia de ondas $\mathrm{Q}$ y $\mathrm{R}$ en algunas ocasiones, los complejos QRS y segmentos ST cortos o ausentes. Tanto la presentación como el tamaño y calidad de las deflexiones registradas en el ECG varían en cada derivada y en cada animal. En la derivada I la mayoría de animales presentaron un trazado isoeléctrico con deflexiones muy pequeñas y complejos QRS difíciles de definir.

La derivada $\mathrm{aVL}$ fue la más homogénea entre todos los animales, presentando un trazado regular, de buena calidad y con la mayoría de las deflexiones presentes y fáciles de medir. En cuanto a las deflexiones, la onda $\mathrm{P}$ en todas las derivadas fue demasiado pequeña haciendo difícil realizar una medición confiable, mientras que la onda $R$ fue difícil de obtener en la mayoría de las derivadas bipolares, pero no siendo así en las derivadas unipolares aumentadas en donde su registro fue frecuente. La onda S estuvo ausente o fue difícil de distinguir en las derivadas $a V R$ y $a V L$, mientras que en las demás derivadas se identificó fácilmente. Solo dos aves (en derivada I y aVL) no graficaron ninguna deflexión que representara la despolarización ventricular (onda $\mathrm{R}$ o S). Por otro lado, la onda $\mathrm{T}$ estuvo presente en todas las derivadas en casi la totalidad de los animales examinados.

Así como en otras especies, se ha reportado que enfermedades infecciosas y no infecciosas pueden alterar los parámetros electrocardiográficos causando fenómenos como la ampliación de ondas $(P, R, S, T)$, intervalos (PR, TP y $Q R S)$, taquicardias y arritmias ventriculares, contracciones ventriculares prematuras, bradicardia y ondas T altas (13-16). Aunque las aves utilizadas en el presente estudio estaban aparentemente sanas, no se puede descartar algún tipo de patología que pudiera alterar los resultados del ECG.

En un estudio realizado en aves rapaces se encontró una gran variabilidad en la morfología de la onda $\mathrm{P}$ en derivada III [positiva en el $72.5 \%$, negativa en el $15.7 \%$ y bifásica en el $11.8 \%$ de los animales] (8). En el presente estudio se observó que la onda P fue siempre positiva en las derivadas I, II, III y aVF, negativa en aVR y positiva en el $60 \%$ de los animales y negativa en el $40 \%$ en aVL. También se observó el fenómeno de fusión o superposición de ondas T y P en el $17.6 \%$ de los animales ( 3 de 
Table 4. Range comparison for ECG references in Amazona ochrocephala.

\begin{tabular}{lcc}
\hline \multicolumn{1}{c}{ Parameter } & $\begin{array}{c}\text { Range Amazona spp } \\
\text { Nap et al (4) }\end{array}$ & $\begin{array}{c}\text { Range Amazona } \\
\text { ochrocephala (lead II) }\end{array}$ \\
\hline Wave duration P & $0.008-0.07 \mathrm{~s}$ & $0.015-0.044 \mathrm{~s}$ \\
Wave amplitude P & $0.25-0.60 \mathrm{mV}$ & $0.031-0.6 \mathrm{mv}$ \\
Duration PR & $0.042-0.055 \mathrm{~s}$ & $0.021-0.076 \mathrm{~s}$ \\
Duration QRS & $0.010-0.015 \mathrm{~s}$ & $0.036-0.068 \mathrm{~s}$ \\
Amplitude R & $0.00-0.65 \mathrm{mV}$ & $0.034-0.038 \mathrm{mv}$ \\
Amplitude S & $0.70-2.30 \mathrm{mV}$ & $0.19-0.81 \mathrm{mv}$ \\
Duration QT & $0.048-0.070 \mathrm{~s}$ & $0.070-0.154 \mathrm{~s}$ \\
Wave duration T & $0.020-0.035 \mathrm{~s}$ & $0.025-0.064 \mathrm{~s}$ \\
Wave amplitude T & $0.30-0.80 \mathrm{mV}$ & $0.010-0.5 \mathrm{mv}$ \\
EEM & $-107^{\circ}$ to $-90^{\circ}$ & $-111^{\circ}$ to $-80^{\circ}$ \\
FC & $340-600 \mathrm{ppm}$ & $240-600 \mathrm{ppm}$ \\
\hline
\end{tabular}

study only Amazona ochrocephala parrots were included, and the conditions of altitude and pressure were not the same in each case, which can affect the parameters.

This study aspires to make more information available about ECGs in Amazona birds in order to facilitate the clinical practice of this important diagnostic tool and thus contribute to the study of physiology and pathologies of the cardiovascular system in these birds.

\section{Acknowledgments}

To the Unidad de Rescate y Rehabilitación de Animales Silvestres (URRAS), la Clínica para Pequeños Animales (CPA) of the Universidad Nacional de Colombia-Bogotá, Dr. Milena Lamprea, Dr. Ángela Bermúdez and Dr. José Luis Granados for their participation in this study and for sharing their knowledge with us.
17 animales) en las derivadas II, III y aVF y en la mayoría de registros electrocardiográficos las ondas Q y R fueron ausentes o demasiado pequeñas para medirlas.

Finalmente es posible concluir que se obtuvo un trazado electrocardiográfico de muy buena calidad al realizar el procedimiento bajo anestesia general con Isoflurano (Tabla 4). Adicionalmente los resultados obtenidos fueron similares a los reportados en el estudio de Nap et al (4) en lo que se refiere a la duración de ondas $\mathrm{P}, \mathrm{QRS}$ y $\mathrm{T}$, frecuencia cardiaca y eje eléctrico, mientras que la amplitud de ondas $\mathrm{P}, \mathrm{QRS}$ y T fue menor en nuestro estudio. Sin embargo estas diferencias pueden deberse a las condiciones propias de cada estudio; en el estudio de Nap et al (4). se utilizaron loras de la especie Amazona ochrocephala, A. amazónica y A. festiva, mientras que en el presente estudio solo se incluyeron individuos de la especie Amazona ochrocephala, además las condiciones de altitud y presión no fueron las mismas en cada caso lo cual puede afectar los parámetros.

Con este estudio se espera ampliar la información existente sobre la electrocardiografía en aves del género Amazona para así facilitar la práctica clínica de ésta importante herramienta diagnóstica y contribuir así al estudio de la fisiología y patologías del sistema cardiovascular en estas aves.

\section{Agradecimientos}

A la Unidad de Rescate y Rehabilitación de Animales Silvestres (URRAS), la Clínica para Pequeños Animales (CPA) de la Universidad Nacional de Colombia-Bogotá, la Dra. Milena Lamprea, la Dra. Ángela Bermúdez y al Dr. José Luis Granados por su colaboración en el estudio y aportarnos parte de su conocimiento.

\section{REFERENCES}

1. Cruz-Antía D, Gómez JR. Aproximación al uso y tráfico de fauna silvestre en Puerto Carreño, Vichada, Colombia. Ambiente y Desarrollo 2010; 14(26):63-91.

2. Šolc D. The heart and heart conducting system in the kingdom of animals: A comparative approach to its evolution. Exp Clin Cardiol 2007; 12(3):113-118.

3. Richard WN, Couto CG. Pruebas diagnósticas en las enfermedades cardiovasculares. En: Richard WN, Couto CG. Medicina interna de animales pequeños. Cuarta edición. St. Louis, Missouri: ElSevier; 2009.
4. Nap AMP, Lumeji JT, Stokhof AA. Electrocardiogram of the African grey (Psittacus erithacus) and amazon (Amazonas pp. ) parrot. Avian Pathol 1992; 21(1):45-53.

5. Instituto Geográfico Agustín Codazzi. Aspectos prácticos de la adopción del marco geocéntrico nacional de referencia MAGNASIRGAS como datum oficial de Colombia. Subdirección de Geografía y cartografía del Instituto Geográfico Agustín Codazzi. Bogotá. 2004. 
6. López Jiménez VL. Condiciones atmosféricas predominantes en el piedemonte de la cordillera Oriental, determinantes del régimen climático en las sedes de la Universidad de la Salle, Bogotá. Épsilon. 2012; 18:87-104.

7. Hurtado JC, Salazar T, la Peña M de. Valores normales de gases arteriales en Bogotá. Umbral Científico 2007; 10:94-102.

8. Talavera J, Guzmán MJ, del Palacio MJ, Albert AP, Bayón A. The normal electrocardiogram of four species of conscious raptors. Res Vet Sci 2008; 84(1):119-125.

9. Zandvliet MMJM. Electrocardiography in psittacine birds and ferrets. Seminars in Avian and Exotic Pet medicine. 2005; 14(1):34-51.

10. Bavelaar FJ, Beynen AC. Atherosclerosis in parrots. A review. Vet Q 2004; 26(2):50-60.

11. Beaufrère $H$. Avian atherosclerosis: parrots and beyond. Exotic Pet Medicine 2013; 22(4):336-347.
12. Wit M de, Schoemaker NJ. Clinical approach to avian cardiac disease. Seminars in Avian and Exotic Pet Medicine. 2005; 14(1):6-13.

13. Musulin SE, Adin DB. ECG of the month. Sinus arrhythmia in an african grey parrot. J Am Vet Med Assoc 2006; 229(4):505-507.

14. Nalmas S, Nagarakanti R, Slim J, Abter E, Bishburg E. Electrocardiographic changes in infectious diseases. Hospital Physician. 2007; 43(9):15-27

15. Rembert MS, Smith JA, Strickland KN, Tully TNJr. Intermittent bradyarrhythmia in a hispaniolan amazon parrot (Amazona ventralis). J Avian Med Surg 2008; 22(1):31-40.

16. Knafo SE, Rapoport G, Williams J, Brainard B, Driskell E, Uhl E, et al. Cardiomyopathy and right-sided congestive heart failure in a red-tailed hawk (Buteo jamaicensis). J Avian Med Surg 2011; 25(1):32-39. 